\title{
Penerapan Model Pembelajaran Kooperatif Tipe Group Investigation untuk Meningkatkan Kemampuan Siswa dalam Menyusun Teks
}

\author{
Made Sukiasih* \\ SMP Negeri 2 Singaraja, Singaraja, Indonesia
}

\section{A R T I C L E I N F O}

Article history:

Received 20 May 2018

Received in revised form 18 June 2018

Accepted 20 July 2018

Available online 21 August 2018

Kata Kunci:

model pembelajaran

Kooperatif Tipe Group

Investigation, prestasi

belajar

Keywords:

Cooperative learning Group

Investigation Type,

learning achievement.

\begin{abstract}
A B S T R A K
Pelaksanaan penelitian tindakan kelas ini bertujuan untuk mengetahui apakah model pembelajaran Kooperatif Tipe Group Investigation dapat meningkatkan kemampuan siswa dalam menyusun teks. Penelitian ini mengambil subjek pada kelas IX-3 SMP Negeri 2 Singaraja pada semester ganjil Tahun Pelajaran 2017/2018. Data hasil penelitian ini dikumpulkan dengan tes prestasi belajar sedangkan analisisnya menggunakan analisis deskriptif. Setelah semua data dilakukan analisis, diperoleh peningkatan hasil belajar dari awalnya mencapai 74,80 dengan ketuntasan belajar $60,53 . \%$ meningkat pada siklus I rata-rata menjadi 76,69 ketuntasan belajar 73,68.\%. Hasil siklus ke II rata-rata meningkat menjadi 77,61 ketuntasan belajar klasikal $89,47 \%$. Ternyata hasil di siklus II sudah melampui kreteria yang diusulkan sesuai indikator keberhasilan penelitian. Atas dasar perolehan data tersebut peneliti berkesimpulan bahwa model pembelajaran Kooperatif Tipe Group Investigation dapat meningkatkan kemamapuan siswa dalam menyusun teks siswa kelas IX-3 SMP Negeri 2 Singaraja semester ganjil tahun pelajaran 2017/2018.
\end{abstract}

\section{A B S T R A C T}

The implementation of this classroom action research aimed at finding out whether the Cooperative learning Group Investigation Type can improve students' ability in composing text. The subject of this study was the third grade students of SMP Negeri 2 Singaraja in the odd semester of 2017/2018 Academic Year. The data of this research were collected using learning achievement test while the analysis used was descriptive analysis. After all data were analyzed, it was found an improvement in learning outcomes. The average score of the students before the research was 74.80 with learning completeness $60.53 . \%$. Then, in the first cycle, the average score was 76.69 with learning completeness $73.68 \%$. The results of the second cycle also improved with the average score 77.61 and classical learning completeness $89.47 \%$. It turned out that the results in cycle II had exceeded the criteria proposed according to the indicators of success of the study. Based on the data gained, the researcher concluded that the Cooperative Learning model Group Investigation Type can improve the ability of students composing the text. 


\section{Pendahuluan}

Kondisi pembelajaran Bahasa Indonesia terutama menyusun teks bagi siswa di kelas saat ini masih sangat rendah kualitasnya. Hal ini terlihat dari kemampuan siswa yang belum memenuhi KKM yang disyaratkan. Hal ini disebabkan oleh pembelajaran yang dilaksanakan oleh guru di kelas dengan pendekatan ekspositoris dan guru hanya memberikan materi dengan metode ceramah, belum melibatkan siswa secara langsung mengamati wacana yang harus dipahami. Akibatknya mata pelajaran Bahasa Indonesia yang sangat strategis sangat susah dipelajari oleh siswa, utamanya aspek pemahaman terhadap isi wacana.

Permasalahan tersebut dipengaruhi oleh belum maksimalnya guru dalam berinovasi mamanfaatkan model-model pembelajaran yang efektif meningkatkan keterlibatan siswa dalam proses pembelajaran. Sehingga pembelajaran yang dilakukannya lebih berorietasi pada ketuntasan materi, bukan pada kebermaknaan pembelajaran bagi peserta didik. Tujuan dan kepentingan belajar peserta didik terabaikan selama pembelajaran berlangsung, karena mereka hanya dijadikan objek pembelajaran, sehingga motivasi, aktivitas siswa dalam proses pembelajaran menjadi semakin menurun, dan serta merta mengakibatkan nilai prestasi belajar siswa sangat rendah.

Pembelajaran Bahasa Indonesia hendaknya didesain untuk dapat memberikan kesempatan kepada siswa, menumbuhkembangkan kemampuannya secara maksimal dalam memanfaatkan Bahasa Indonesia secara baik dan benar, berkomunikasi menurut kaidah-kaidah yang baik dan benar, serta mamahami atau memaknai informasi tertulis seperti wacana sebagai bahan pembelajaran. Dalam pembelajaran hendaknya siswa diberi kemandirian untuk belajar dengan memanfaatkan aneka sumber belajar yang ada, sehingga belajar bisa dimana-mana, belajar bisa dengan siapa saja, belajar bisa kapan saja.

Sejalan dengan pandangan tersebut maka pembelajaran kooperatif tampaknya merupakan strategi yang paling sesuai. Dalam pembelajaran kooperatif siswa harus mampu untuk bekerja sama dalam kelompok kecil yang heterogen, adanya ketergantungan positif (saling membutuhkan), saling membantu, dan saling memberikan motivasi. Pada saat belajar kooperatif sedang berlangsung, guru terus melakukan pemantauan melalui obsevasi dan penekanan belajar tidak hanya pada penyelesaian tugas tetapi juga hubungan interpersonal.

Hasil observasi awal menunjukan bahwa nilai prestasi belajar siswa kelas IX-3 SMP Negeri 2 Singaraja sangat rendah, dan tidak memenuhi target pencapaian minimal, dimana rata-rata prestasi belajar pada aspek menyusun teks baru mencapai 74,80 ketuntasan belajar 60,53\%. Melalui refleksi awal didapatkan hasil analisis kondisi, terindikasi bahwa kondisi ini disebabkan bahwa proses pembelajaran Bahasa Indonesia di sekolah masih; (1) dominasi guru yang berlebihan selama pembelajaran, (2) komunikasi pembelajaran hanya bersifat satu arah, (3) guru hanya menggunakan metode ceramah saja, (4) layanan kesulitan belajar siswa oleh guru sangat kurang, (5) sumber pembelajaran hanya berupa buku teks, (6) guru tidak memberikan kebebasan kepada peserta didik untuk belajar secara mandiri maupun berkelompok, dan (7) evaluasi yang dilaksanakan oleh guru hanya berupa hasil belajar berupa pengetahuan saja, mengabaikan evaluasi proses.

Permasalahan yang terjadi dalam pembelajaran tersebut dapat ditanggulangi dengan mengubah pandangan, dari pandangan konvensional yang lebih memosisikan pendekatan pembelajaran pada upaya pemindahan pengetahuan secara utuh, menuju pandangan inovatif yaitu pendekatan pembelajaran kooperatif, yang lebih memosisikan pembelajaran pada upaya self-cooperation, di mana pengetahuan itu dibangun di dalam pikiran peserta didik dan oleh peserta didik itu sendiri, dengan difasilitasi guru untuk mengadakan kerjasama dengan siapa saja termasuk siswa lainnya. Pendekatan yang dimaksud adalah belajar aktif, konstruktivistik, dan kooperatif.

Model kooperatif Tipe Group Investigation sebagai solusi penanggulangan permasalahan tersebut, termasuk dalam pembelajaran kooperatif. Salah satu ciri pembelajaran kooperatif adalah kemampuan siswa untuk bekerja sama dalam kelompok kecil yang heterogen (Suyitno, 2004: 9). Masing-masing anggota dalam kelompok memiliki tugas yang setara. Dalam model kooperatif Tipe Group Investigation, siswa ditempatkan dalam kelompok-kelompok kecil (4 sampai 5 siswa) yang heterogen untuk menyelesaikan tugas kelompok yang sudah disiapkan oleh guru, selanjutnya diikuti dengan pemberian bantuan secara individu bagi siswa yang memerlukannya. Keheterogenan kelompok mencakup jenis kelamin, ras, agama (kalau mungkin), tingkat kemampuan (tinggi, sedang, rendah), dan sebagainya. Kemudian guru memberikan tes formatif sesuai dengan standar kompetensi dan kompetensi dasar yang ditentukan.

Model pembelajaran kooperatif telah diyakini oleh banyak ahli pendidikan sebagai model pembelajaran yang dapat memberi peluang siswa untuk terlibat dalam diskusi, berpikir kritis, berani dan mau mengambil tanggung jawab untuk pembelajaran mereka sendiri (Gokhale, 1995). Meskipun model pembelajaran kooperatif mengutamakan peran aktif siswa bukan berarti guru tidak berpartisipasi, sebab 
dalam proses pembelajaran guru berperan sebagai perancang, fasilitaor dan pembimbing proses pembelajaran (Syaodih, 2007). Model pembelajaran kooperatif tipe group investigasi dapat dipakai guru untuk mengembangkan kreativitas siswa, baik secara perorangan maupun kelompok, karena model pembelajaran ini dirancang untuk membantu terjadinya pembagian tanggung jawab ketika siswa mengikuti pembelajaran dan berorientasi menuju pembentukan manusia sosial (Mafune,2005).

Dipilihnya penanggulangan permasalahan tersebut karena beberapa temuan hasil penelitian terdahulu membuktikan bahwa model kooperatif dapat dijadikan sebagai alternatif strategis untuk mengurangi berbagai masalah seputar rendahnya kualitas dan hasil pembelajaran. Penelitian dimaksud seperti; Sutama (2007) pada sebuah penelitiannya yang berjudul Model pembelajaran kooperatif tipe group investigation untuk mengembangkan kreativitas mahasiswa jurusan pendidikan matematika FKIP UMS Surakarta, menyimpulkan bahwa; penggunaan model pembelajaran kooperatif tipe group investigation dapat meningkatkan kemampuan berpikir kreatif, dan prestasi akademik mahasiswa. Sebagai sebuah model pembelajaran, model ini tampaknya cukup teruji efektivitasnya dalam meningkatkan perolehan prestasi belajar peserta didik, namun yang perlu dikaji lebih jauh adalah bagaimana halnya dengan aplikasi model ini terhadap peningkatan aktivitas dan prestasi belajar siswa pada mata pelajaran Bahasa Indonesia di SMP khususnya aspek menyusun teks.

Dari latar belakang permasalahan yang telah dipaparkan sebelumnya, maka rumusan permasalahan penelitian ini adalah apakah model pembelajaran kooperatif tipe group investigation dapat meningkatkan kemampuan menyusun teks bagi siswa kelas IX-3 SMP Negeri 2 Singaraja semester ganjil tahun pelajaran $2017 / 2018$ ?

Penelitian ini bertujuan untuk meningkatkan kemampuan menyusun teks siswa kelas IX-3 SMP Negeri 2 Singaraja pada semester ganjil tahun pelajaran 2017/2018 melalui penerapan model pembelajaran kooperatif tipe group investigation.

Manfaat yang akan diperoleh dari kegiatan penelitian ini adalah; Bagi siswa, penerapan pembelajaran kooferatif tipe Group Investigation ini akan memberikan pengalaman belajar yang sangat efektif dengan aktivitas belajar yang sangat efektif pula, sehingga secara serta merta pembelajaran menjadi bermakna, juga berakibat kepada penguasaan materi pelajaran secara tuntas. Bagi guru mata pelajaran Bahasa Indonesia; adanya suatu alternatif serta variasi model pembelajaran yang dapat diterapkan dalam proses pembelajaran guna menanggulangi masalah dalam proses pembelajaran. Bagi pengemban profesi keguruan secara umum; akan didapat pola sikap profesional guru, dengan menyadari kelemahan kualitas proses pembelajaran dan pencarian solusi untuk mengatasinya. Bagi birokrat kependidikan; hasil penelitian ini bermanfaat sebagai referensi dalam pembinaan mutu pendidik dan tenaga kependidikan menuju peningkatan kualitas tenaga pendidik.

\section{Metode}

Jenis penelitian yang dipilih adalah penelitian tindakan kelas (Classroom Action Research). Dipilihnya jenis penelitian ini adalah karena penelitian tindakan kelas, merupakan suatu bentuk kajian yang bersifat reflektif oleh pelaku tindakan, yang dilakukan untuk meningkatkan kemampuan rasional dari tindakan-tindakan mereka dalam melaksanakan tugas, memperdalam pemahaman terhadap tidakantindakan yang dilakukannya itu, serta memperbaiki kondisi kelas tempat praktek tindakan tersebut (Depdikbud 1999: 6).

Penelitian ini dilaksanakan di kelas IX-3 SMP Negeri 2 Singaraja, dengan jumlah siswa 38 orang. dengan rata-rata nilai dan ketuntasan belajar sangat rendah. Dari rata-rata KKM yang ditentukan 75 , kelas ini hanya mampu meraih nilai rata-rata 74,80 dan ketuntasan belajar $60,53 \%$. Argumentasi terpenting pelaksanaan penelitian pada kelas ini dimaksudkan agar peneilitan memiliki asas manfaat sesuai dengan karakteristik penelitian tindakan kelas tersebut.

Waktu pelaksanaan penelitian pada semester ganjil tahun pelajaran $2017 / 2018$, yaitu mulai bulan Juli 2016 dilaksanakan persiapan penelitian sampai dengan pelaksanaan penyusunan laporan hasil penelitian pada bulan Nopember 2016.

Prosedur pelaksanaan tindakan setiap siklusnya secara berdaur meliputi Langkah-langkah; identifikasi masalah, perencanaan tindakan, pelaksanaan tindakan, pengamatan/observasi dan pengumpulan data, refleksi, perencanaan ulang. Tahapan ini dimaksudkan untuk merencanakan langkahlangkah penyempurnaan kelemahan-kelemahan yang ditemukan pada tindakan sebelumnya, sesuai temuan dan hasil refleksi terdapat hal-hal yang perlu dilakukan proses pengkajian ulang melalui siklus berikutnya. Lebih jelasnya prosedur siklus penelitai dimaksud dapat disajikan pada gambar siklus berikut; 


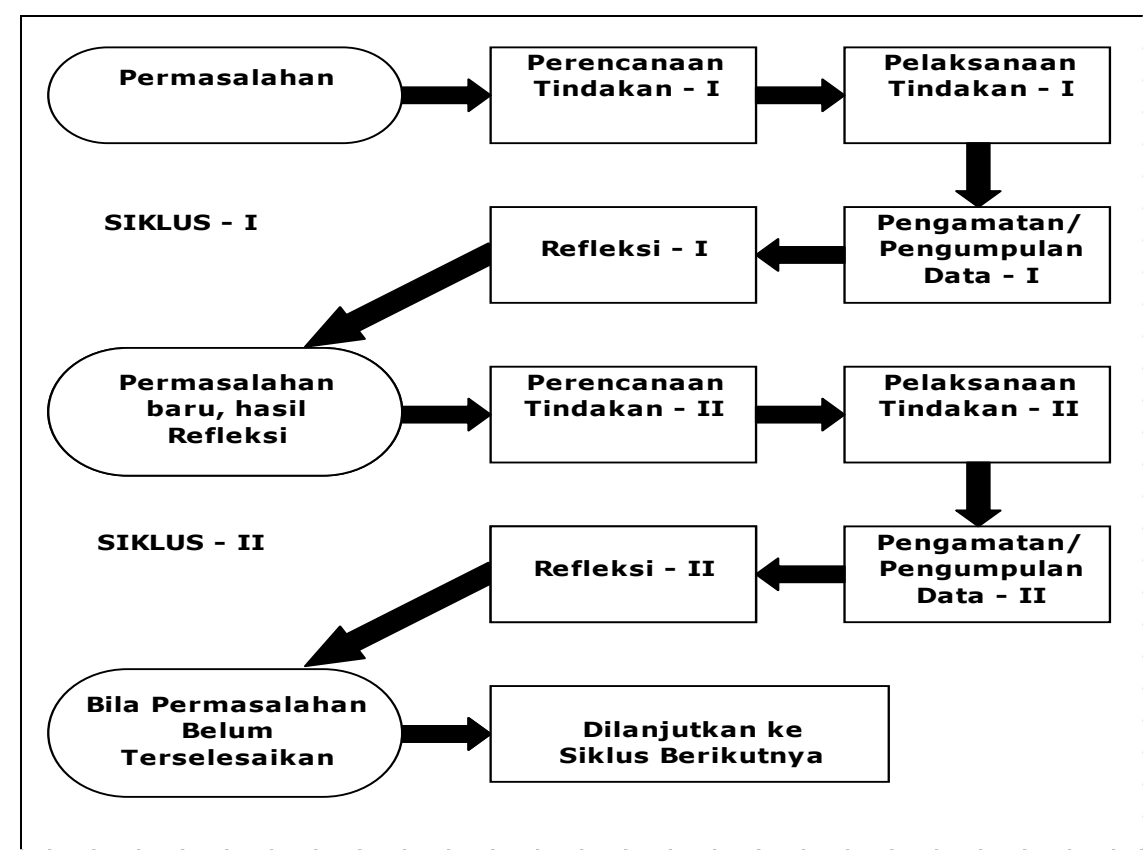

Gambar 1. Siklus Penelitian Tindakan (Sumber : depdiknas: 2009)

Aspek yang diamati dalam penelitian ini adalah implementasi model pembelajaran kooferatif tipe group investigation, dan kemampuan menyusun teks, Dengan demikian maka dalam penelitian ini data yang diinginkan adalah informasi tentang bagaimana terjadinya peningkatan kemampuan siswa dalam menyusun teks yang dikumpulkan melalui rubrik penilaian puisi Data yang diperoleh diolah atau dianalisis dengan analisis deskriptif. Hasil analisa data berupa rata-rata dan ketuntasan belajar, yang digunakan untuk memutuskan pelaksanaan tindakan dianggap berhasil jika sesuai dengan kriteria keberhasilan, dan dianggap gagal bila tidak sesuai dengan kriteria keberhasilan.

Kreteria keberhasilan penelitian ini dapat diukur dari ketercapaian hasil penelitian terhadap kemampuan siswa dalam menyusun teks. Jika hasil penelitian pada siklus I dan siklus II telah mencapai rata-rata minimal KKM atau lebih dengan ketuntasan belajaran minimal 85\% atau lebih. KKM yang ditentukan adalah 75 .

\section{Hasil dan Pembahasan}

Pada bagian ini, disajikan hasil pelaksanaan penelitian tindakan tiap siklus dan rekapitulasi hasil secara keseluruhan. Penyajian hasil berupa proses kegiatan pelaksanaan implementasi model pembelajaran, dan data hasil dalam bentuk rata-rata hasil prestasi belajar aspek kemampuan menyusun teks.

Kemampuan siswa masih belum memenuhi KKM dengan rata-rata yang dipersyaratkan adalah 75 namun baru tercapai 74,80 dan ketuntasan belajar klasikal idial sehurnya $85 \%$ ternyata beru tercapai $60,53 \%$. Untuk menanggulangi permasalahan itulah maka penelitian ini dilaksanakan.

Setelah teridentifikasi permasalahan yang harus dipecahkan, maka pada tahap ini dilaksanakan kegiatan merencanakan penanggulangan permasalahan dengan kegiatan; (1) Menyusun rencana program pembelajaran, (2) Menyusun instrumen observasi pelaksanaan sintak pembelajaran kooperatif tipe group investigation. (3) Menyusun perangkat tes prestasi hasil belajar, untuk mengukur tingkat penguasaan atau kektuntasan penguasaan materi yang diajarkan. (4) Menentukan topik permasalahan dan bahan ajar yang dipergunakan dalam proses pembelajaran berkaitan dengan standar kompetensi dan kompetensi dasar yang harus dikuasai siswa. (5) Mempersiapkan media, alat-alat pembelajaran, dan LKS yang diperlukan.

Sesuai rencana, pelaksanaan implementasi pembelajaran pada setiap siklus melalui tigakali pertemuan. Langkah langkah yang dilaksanakan yakni; (1) perencanaan topik (Planing), (b) pengelompokan siswa (Grouping), (c) penyelidikan topik (Investigation), (d) pengorganisasian hasil (Organizing), (e) presentasi hasil (Presenting), (f) evaluasi (evaluating),

Kegiatan observasi dilaksanakan bersamaan dengan pelaksanaan kegiatan implementasi pembelajaran dikelas. Pelaksanan implementasi pembelajaran dilaksanakan langsung oleh peneliti, sedangkan observer dibantu oleh guru mata pelajaran Bahasa Indonesia lain yang tidak mengajar di kelas 
ini. Hasil observasi terhadap pertemuan satu, dua dan tiga diperoleh data tentang pelaksanaan pembelajaran menggunakan strategi kooperatif tipe group investigation seperti rata-rata 76,69 dan ketuntasan belajar klasikal 73,68\%.

Pada tahap refleksi menemukan keunggulan Siklus I adalah; (1) Mulai kelihatan pembelajaran sesuai dengan standar proses walaupun masih perlu ditingkatkan lagi, (2) pada aktivitas belajar siswa, secara rata-rata aspek pelaksanaan investigasi terkategori baik. Hasil ini menandakan bahwa; siswa mulai membangun konsep materi sendiri, sebagai akibat dari pembelajaran yang sudah berpusat pada siswa. (3) Sedangkan pada hasil prestasi belajar, menunjukkan aspek rata-rata dan daya serap siswa sudah mencapai KKM, walaupun ketuntasan klasikalnya belum memenuhi kriteria yang ditentukan.

Selain keunggulan juga ditemukan kelemahan siklus I diantaranya; (1) Implementasi model pembelajaran, masih belum sesuai dengan sintaks yang ditentukan, (2) nilai rata-rata kemampuan siswa menyusun teks belum sesuai indikator keberhasilan, (3) aktivitas siswa dalam pembalajaran secara umum masih sangat lemah.

Hasil refleksi sebelumnya teridentifikasi permasalahan yang harus ditanggulani adalah; (a) penggunaan waktu kurang efektif. (b) guru belum menentukan resuma pelaksanaan proses hasil pembelajaran, (c) guru tidak melaksanakan konfirmasi terkait hasil diskusi yang ditekankan pada indikator pembelajaran. Untuk itu dilaksanakan kembali penelitian di siklus II.

Pada prinsipnya secara umum penyusunan rencana pembelajaran sama seperti pertemuan sebelumnya, cuma dilaksanakan penyempurnaan pada bagian yang belum sesuai, terutama pembentukan kelompok investigasi dilaksanakan akhir jam pelajaran sebelumnya, sehingga penggunaan waktu menjadi lebih efektif.

Tahapan sintak implementasi model pembelajaran pada siklus kedua ini juga sama seperti siklus sebelumnya, sehingga dirasa tidak terlalu penting untuk disampaikan kembali karena merupakan pengulangan saja. Karena penelitian ini merupakan proses yang berdaur dan bersiklus, maka yang disampaikan selanjutnya adalah hal-hal yang berbeda dengan pertemuan dan siklus sebelumnya. Hal lainnya sama seperti pada pertemuan sebelumnya mengikuti langkah-langkah yang telah direncanakan, baik kegiatan siswa maupun kegiatan guru, mulai kegiatan investikasi, presentasi dan sampai akhirnya evaluasi.

Hasil observasi menemukan data dan fakta bahwa rata-rata kemampuan siswa menyusun teks telah mencapai 77,61 yang artinya telah meleibihi indikator keberhasilan, demikian juga ketuntasan belajar klasikal telah mencapai 89,47\%.

Keunggulan pelaksanaan sintak pembelajaran telah sesuai dengan standar proses pembelajaran dapat diamati dalam suasana pembelajaran yang sangat kooperatif dan tidak secara eksplisit, namun pada setiap tahapan terdapat kegiatan dimaksud terjadi. Aktivitas belajar siswa menampakkan trend menuju kesempurnaan, hal ini mengindikasikan bahwa pembelajaran dengan strategi ini mulai terkondisikan atau teradaftasi pada mind-set siswa dengan baik. Hasil prestasi belajar, dalam menyusun teks terlihat adanya trend peningkatan. Jika diukur dengan KKM, secara individu siswa tuntas sudah meningkat jika dibandingkan dengan siklus satu sebelumnya, dan secara langsung juga berarti siswa yang tidak tuntas mengalami penurunan. Rata-rata dan daya serap siswa tergolong tinggi.

Walaupun secara umum pelaksanaan siklus kedua pada setiap pertemuan terdapat keunggulankeunggulan, namun jika dikaji ternyata masih juga terdapat kelemahan-kelemahannya, seperti; aktivitas belajar siswa masih belum maksimal, masih terdapat rata-rata 4 orang yang belum tuntas.

Pekembangan rata-rata kemampuan siswa dalam menyusun teks yang ditandai dengan adanya perkembangan nilai rata-rata, dan ketuntasan belajar siswa juga terjadi secara positif. Refleksi awal ratarata prestasi hasil belajar siswa 74,80 dengan ketuntasan 60,53 \%. Selanjutnya setelah implementasi model kooperatif Tipe Group Investigation, selama dua siklus, secara umum telah terjadi peningkatan pada rata-rata prestasi dan ketuntasan hasil belajar, hasil yang diraih pada siklus pertama rata-rata kemampuan menyusun teks 76,69 ketuntasan belajar $73,68 \%$ dan pada siklus kedua rata-rata kemampuan menyusun teks 77,61 ketuntasan belajar mencapai 89,47 \%.

Hasil implementasi model pembelajaran kooperatif Tipe Group Investigation menampakkan adanya keberhasilan dalam meningkatkan aktivitas belajar siswa, yang diikuti dengan peningkatan prestasi belajar siswa. Hal ini sesuai dengan kajian pustaka, dan dapat diketahui bahwa peningkatan tersebut adalah merupakan konskuensi logis dari pemilihan strategi ini untuk penanggulangan masalah pembelajaran pada kelas ini. Anderson dan Faust (1982), menyatakan kegiatan pembelajaran dengan pendekatan kooperatif akan mampu mencapai minimal empat tujuan yakni: 1) Memelihara motivasi dan aktivitas belajar siswa; 2) meningkatkan perhatian siswa; 3) membantu siswa dalam memahami konsep materi pelajaran; 4) Menjaga ingatan siswa agar tidak mudah melupakan materi pelajaran yang pernah diberikan. 
Model pembelajaran kooperatif Tipe Group Investigation sering dipandang sebagai metode yang paling kompleks dalam pembelajaran kooperatif, karena melibatkan siswa sejak perencanaan, baik dalam menentukan topik maupun cara untuk mempelajarinya melalui investigasi. Model pembelajaran ini menuntut para siswa untuk memiliki kemampuan yang baik dalam berkomunikasi maupun dalam ketrampilan proses kelompok (group process skills), karena guru yang menggunakan model pembelajaran kooperatif Tipe Group Investigation umumnya membagi kelas menjadi kelompok dengan karakteristik anggota yang heterogen.

Argumentasi lain terhadap keberhasilan yang dicapai dari penelitian ini adalah; secara umum dalam model pembelajaran kooperatif Tipe Group Investigation dikembangkan keterampilan berpikir kritis dan kerja sama, hubungan antara pribadi yang positif dari latar belakang yang berbeda, menerapkan bimbingan antar teman, dan tercipta lingkungan yang menghargai nilai-nilai ilmiah yang dapat membangun motivasi belajar pada siswa. Melalui model pembelajaran kooperatif Tipe Group Investigation keaktifan siswa lebih tinggi sebab siswa mendapatkan pengalaman langsung. Hasil penelitian ini juga dikuatkan oleh hasil penelitian yang pernah dilaksanakan Johnson dan Johnson (Nurhadi dkk, 2003: 62) menunjukkan adanya berbagai keunggulan model pembelajaran kooperatif yakni: (1) Memudahkan siswa melakukan penyesuaian sosial; (2) Mengembangkan kegembiraan belajar yang sejati; (3) Memungkinkan para siswa saling belajar mengenai sikap; keterampilan, informasi, perilaku sosial dan pandangan: (4) Meningkatkan rasa saling percaya kepada sesama manusia; (5) Meningkatkan kesediaan menggunakan ide orang lain yang dirasakan lebih baik; (6)Meningkatkan motivasi belajar instrinsik; (7) Meningkatkan sikap positif terhadap belajar dan pengalaman belajar.

\section{Simpulan Dan Saran}

Berdasarkan hasil penelitian disimpulkan bahwa penerapan model pembelajaran kooperatif Tipe Group Investigation dapat meningkatkan kemampuan siswa dalam menyusun teks bagi siswa kelas IX-3 SMP Negeri 2 Singaraja semester ganjil tahun pelajaran 2017/2018.

Disarankan kepada: (1) Guru Bahasa Indonesia dalam mengembangkan aktivitas, dan kreativitas belajar siswa pada pembelajaran, hendaknya mempertimbangkan untuk menerapkan startegi pembelajaran kooperatif Tipe Group Investigation mengingat kefektifan model pembelajaran ini dalam menanggulangi permasalahan dimaksud, sehingga kualitas pembelajaran dapat ditingkatkan. (2) Guru mata pelajaran lain dapat dijadikan refrensi dalam menanggulangi rendahnya kualitas pembelajaran, guna optimalisasi peningkatan mutu pendidikan. (3) Dalam implementasinya, guru dapat memvariasikan model pembelajaran kooperatif Tipe Group Investigation dengan model pembelajaran lainnya, sehingga diperoleh model pembelajaran yang lebih sesuai karakteristik pokok bahasan dan kondisi siswa. (4) Penelitian ini hanya sebatas membandingkan hasil belajar menggunakan model pembelajaran kooperatif Tipe Group Investigation dengan model pembelajaran lain non kooperatif yaitu model pembelajaran pengajaran langsung. Perlu dilakukan penelitian dengan membandingkan hasil belajar dengan penerapan tipe-tipe pembelajaran kooperatif lainnya.

\section{Daftar Rujukan}

Arikunto, Suharsimi; Suhardjono; Supardi. 2006. Penelitian Tindakan Kelas. Jakarta: PT Bumi Aksara.

Astuti, Budi. 2017. "Meningkatkan Motivasi dan Hasil Belajar IPS Siswa Kelas VI SD melalui Model Group Investigation”. Mimbar Sekolah Dasar, Volume 4 No 3 Tahun 2017.

Astuti, Ninin dkk. 2013. "Penerapan Model Pembelajaran Kooperatiftipegroup Investigation Untuk Meningkatkan Keaktifan Dan Hasil Belajar Ips Siswa Kelas V Sd Negeri 1 Negari Klungkung”. Mimbar PGSD Undiksha, Volume 1 No 1 Tahun 2013.

Depdiknas. 2011. Membimbing Guru dalam Penelitian Tindakan Kelas. Jakarta: Pusat Pengembangan Tenaga Kependidikan Badan Pengembangan Sumber Daya Manusia Pendidikan dan Menjaminan Mutu Pendidikan.

Husna, M.Ikhsan, dan Siti Fatimah. 2012. Peningkatan Kemampuan Pemecahan Masalah Dan Komunikasi Matematis Siswa Sekolah Menengah Pertama Melalui Model Pembelajaran Kooperatif Tipe ThinkPair-Share (TPS). Jurnal Peluang. Vol. 1, No. 2.

Lubis, Asneli. 2012. Pengaruh Model Pembelajaran Kooperatif Tipe Stad Terhadap Hasil Belajar Fisika 
Siswa Pada Materi Pokok Gerak Lurus Di Kelas X SMA Swasta Uisu Medan. Jurnal Pendidikan Fisika. Vol. 1, No. 1.

Ratna Wilis. 1989. Teori-Teori Belajar. Jakarta: Erlangga.

Sabayasa, Modul materi 2. http://sumberbelajar.belajar.kemdikbud.go.id/

Sadia, I Wayan. 1997. Pembelajaran Kooperative dalam pembelajaran IPA, Makalah dalam seminar sehari. STKIP Negeri Singaraja.

Saefudin Azwar. (1998). Metode Penelitian.Yogyakarta: Pustaka Pelajar Ofset

Slameto. (2003). Belajar dan Faktor-faktor yang Mempengaruhinya.Jakarta: Rineka Cipta

Suhardjono. 2011. Pertanyaan dan Jawaban di Sekitar Penelitian Tindakan Kelas dan Penelitian Tindakan Sekolah. Malang: Cakrawala Indonesia.

Sutama, 2007. Model Pembelajaran Kooperatif Tipe Group Investigation untuk mengembangkan Kreativitas Mahasiswa, Hasil penelitian Jurusan Pendidikan Matematika FKIP Universitas Muhammadiyah Surakarta.

Sunilawati, Ni Made, Nyoman Dantes dan I Made Candiasa. 2013. Pengaruh Model Pembelajaran Kooperatif Tipe Stad Terhadap Hasil Belajar Matematika Ditinjau Dari Kemampuan Numerik Siswa Kelas IV SD. e-Journal Program Pascasarjana Universitas Pendidikan Ganesha. Vol. 3, No. 1.

Syaodih. Erliany. 2007. Pengembangan Model Pembelajaran Kooperatif Untuk Meningkatkan Keterampilan Sosial. Educare. Vol. 5, No. 1. 